\title{
Wincentego Lutosławskiego religia narodu
}

\author{
Marek Nowak \\ (Uniwersytet Warszawski, Instytut Filozofii)
}

\section{Rola niezwykłej duchowości Wincentego Lutosławskiego w kształtowaniu jego poglądów}

Wincenty Lutosławski był niewątpliwie myślicielem niezwykłym, o czym mogą świadczyć jego bogaty życiorys oraz oryginalność myśli.

Celem niniejszego artykułu jest ukazanie, że Lutosławski stworzył światopogląd, który można określić jako patriotyzm podniesiony do rangi religii. Jeśli przyjrzymy się owej koncepcji, to nietrudno zauważyć, że jest ona trudna do przyjęcia zarówno z punktu widzenia chrześcijaństwa, jak i świeckiego patriotyzmu. Dla chrześcijan trudne do zaakceptowania jest to, że naród w owej wizji staje się rodzajem świętej wspólnoty alternatywnej względem Kościoła, a poczucie więzi łączących członków tejże wspólnoty jest zjednoczeniem o charakterze quasi-mistycznym. Z kolei dla laickiego patrioty jakiekolwiek wprowadzanie elementów religijnych do istoty narodowej autoidentyfikacji jest czymś równie niedopuszczalnym.

Filozof miał niespokojną osobowość, co powodowało, że przez większą część życia był zdolny do ogromnej aktywności i niekonwencjonalnych zachowań, które uniemożliwiły mu znalezienie lub utrzymanie pracy na np. uniwersytetach w Krakowie, a potem w Wilnie1. Do happeningów, które według krakowskiej ka-

T. Mróz, „Metafizyka” Wincentego Lutosławskiego, w: W. Lutosławski, Metafizyka, Muzeum Przyrody w Drozdowie, Drozdowo 2004, s. X, XII-XIII. 
dry profesorskiej nie licowały ze statusem profesora, uznano wygłoszenie przemówienia $\mathrm{w}$ stroju góralskim $\mathrm{z}$ płotu w Parku Jordana. Poza tym Lutosławski propagował metody terapeutyczne, które Apolinary Tarnawski stosował w prowadzonym przez siebie sanatorium w Kosowie. W wyniku tego po Krakowie zaczęły krążyć plotki, jakoby Lutosławski prowadził zajęcia w stroju Adama. Jest to najlepszym dowodem na to, że jego wykłady odbywały się w atmosferze sensacji i dlatego gromadziły dosyć spore grono słuchaczy². Wspomniane wydarzenia miały miejsce wyłącznie w dosyć krótko trwającym okresie jego pobytu w Krakowie, co pozwala domyślać się, że jego życie obfitowało w równie interesujące sytuacje.

Filozof pozostawił po sobie dosyć dużą ilość publikacji (również obcojęzycznych) i posiadał ogromne grono znajomych na całym świecie. Należeli do niego np. bł. Karol de Foucauld, William James oraz Henri Bergson; Lutosławski nawiązał znajomość korespondencyjną z Mahatmą Gandhim³.

Jednym ze świadectw niepospolitości Lutosławskiego może być treść pewnej książki, a zwłaszcza dołączona do niej wklejka, w której umieścił faksymile swoich słów. Niewątpliwie w takim miejscu i w takiej formie autor zazwyczaj pragnie zawrzeć coś, co stanowi klucz do rozumienia jego myśli, coś, co stanowi niejako najcenniejszy dar dla czytelników. Otóż we wspomnianej wklejce filozof stwierdza, że każdy czytelnik jest „odwiecznym i nieśmiertelnym duchem, czasowo uwięzionym w ciele”. Filozof napisał tam również, że Nieśmiertelność duszy. Zarys metafizyki polskiej (bo to o tę książkę chodzi) zawiera prawdy „od dawna głoszone przez wieszczów” i że stanowi „pierwszą w literaturze polskiej obiektywną syntezę wiedzy świętej narodu dotąd fragmentarycznie objawionej”". Przedstawione myśli są dla nas istotne, jeśli chcemy zrozumieć sens koncepcji głoszonych przez Lutosławskiego.

Pierwsza przytoczona wyżej myśl jest nawiązaniem do doświadczenia przeżytego przez filozofa w 1885 roku - miał on wtedy uświadomić sobie swoją odwieczną egzystencję duchową i owo doznanie porównywał potem do doświadczenia piękna zawartego w Platońskiej Uczcie oraz tego, które zostało opi-

2 T. Mróz, Wincenty Lutosławski (1863-1954). Jestem obywatelem utopii, PAU, Kraków 2008, s. $119-127,134$.

3 H. Floryńska, Problematyka filozoficzna neoromantyzmu i Młodej Polski, w: Zarys dziejów filozofii polskiej 1815-1918, pod red. Andrzeja Walickiego, PWN, Warszawa 1983, s. 283; T. Mróz, Wincenty Lutosławski (1863-1954), s. 163; T. Mróz, „Metafizyka” Wincentego Lutosławskiego, s. IX.

4 W. Lutosławski, Nieśmiertelność duszy. Zarys metafizyki polskiej, Arct, Warszawa 1925, wklejka. 
sane w Mickiewiczowskim wierszu Widzenie ${ }^{5}$. Doświadczenie przeżyte przez Lutosławskiego w wieku 22 lat może być uznane za rodzaj mistyki jaźni ${ }^{6}$ i było ono czynnikiem, który wyznaczył prawie całą późniejszą tworzoną przez niego filozofię. Również poemat Widzenie powinien być uznany za klucz do rozumienia poglądów neomesjanisty na temat mistyki. Skoro dla Lutosławskiego szczególnym autorytetem byli polscy poeci romantyczni, to nietrudno się domyślić, że filozof $\mathrm{z}$ w swojej refleksji musiał dotknąć tak ważnego dla nich problemu, jak szczególne posłannictwo narodu polskiego oraz innych narodów. Zdaniem Haliny Floryńskiej jednym z ważniejszych elementów filozofii Lutosławskiego był odrodzony romantyczny mesjanizm, który nie stanowił tylko zespołu postulatów etycznych, ale był systemem metafizycznym ${ }^{7}$

\section{Znaczenie mistyki w poglądach Wincentego Lutosławskiego}

Jak już wcześniej wspomniałem, dla neomesjanisty niezwykle ważnym świadectwem doświadczenia mistycznego jest Mickiewiczowski poemat Widzenie. Lutosławskiemu istotne wydały się te partie wiersza, w którym zostało opisane doświadczenie unicestwienia ciała, a z drugiej strony uzyskania natychmiastowego wglądu w całość rzeczywistości ${ }^{8}$.

Przyjrzyjmy się na początek temu, w jaki sposób Mickiewicz opisał niezwykle doświadczenie wewnętrzne.

Dźwięk mię uderzył - nagle moje ciało,

Jak ów kwiat polny, otoczony puchem,

Prysło, zerwane anioła podmuchem,

I ziarno duszy nagie pozostało.

I zdało mi się, że się nagle zbudził

Ze snu strasznego, co mię długo trudził

5 T. Mróz, Wincenty Lutosławski (1863-1954), s. 42, Wincenty Lutosławski, Jeden łatwy żywot, Fundacja im. Wincentego Lutosławskiego, Kraków 1994, s. 109.

6 J.A. Kłoczowski, Profesor Henryk Elzenberg o religii i mistyce, „Znak - Idee” 1990, t. 3, s. 23.

7 H. Floryńska, Problematyka filozoficzna neoromantyzmu i Młodej Polski, dz. cyt., s. 287.

8 W. Lutosławski, L’extase mystique, Hermann, Paris 1937, s. 154.

9 A. Mickiewicz, Widzenie, w: tegoż, Dzieła, t. I, „Czytelnik”, Warszawa 1955, s. 412. 
W opisie owego przeżycia podkreślany jest dualizm dusza-ciało. Duchowy aspekt ludzkiej natury był dotąd obciążony materią, dlatego trwał w stanie snu dlatego też nowe doświadczenie zostało określone za pomocą charakterystycznej dla gnozy metafory przebudzenia. „Nagie ziarno duszy” zdobyło nadzwyczajną wiedzę:

Ziemię i cały świat, co mię otaczał,

Gdzie dawniej dla mnie tyle było ciemnic,

Tyle zagadek i tyle tajemnic

I nad którymi jam dawniej rozpaczał,

Teraz widziałem jak[o] [w] wodzie na dnie,

Gdy [na] nią ciemną promień słońca padnie ${ }^{10}$.

Nowa wiedza była zarazem doświadczeniem jedności zarówno z Bogiem, jak i z naturą:

Teraz widziałem całe wielkie morze, Płynące z środka, jak ze źródła, z Boga, A w nim rozlana była światłość błoga. I mogłem latać po całym przestworze, Biegać, jak promień, przy boskim promieniu Mądrości bożej; i w dziwnym widzeniu I światłem byłem, i źrenicą razem [...]. A w środku siebie, jakby w ognisku, Czułem od razu całe Przyrodzenie ${ }^{11}$.

Wspomniany wyżej podwójny - boski i zarazem kosmiczny - charakter mistyki jest charakterystyczny również dla poglądów Lutosławskiego. Jest to mistyka przyrody (przeciwstawna względem mistyki jaźni), jednak owe dwa typy doświadczenia mogą być w paradoksalny sposób złączone ${ }^{12}$.

Aby ukazać koncepcję mistyki stworzoną przez filozofa, należy opisać ją w kontekście tego, jak były przez niego rozumiane inne rodzaje poznania. Lutosławski zaproponował koncepcję różnych elementów tworzących naszą wiedzę, a co za tym idzie, prowadzących do stworzenia kolejnych systemów filozoficz-

\footnotetext{
10 Tamże.

11 Tamże.

12 J.A. Kłoczowski, Profesor Henryk Elzenberg o religii i mistyce, dz. cyt., s. 23.
} 
nych. Poznanie uzyskujemy dzięki zmysłom i rozumowaniu, jednak istotną rolę w owych procesach może odegrać również ćwiczenie woli oraz natchnienie. Świadome działanie woli prowadzi do odkrycia jaźni, zaś natchnienie otwiera drogę do intuicji mistycznej, czyli ekstazy, podczas której poznajemy Boga ${ }^{13}$. Ekstazę Lutosławski był skłonny również definiować jako zjednoczenie dwóch bytów duchowych, jednego wyższego, drugiego niższego, czyli człowieka-mistyka z Bogiem $^{14}$.

Zdaniem filozofa cała istniejąca rzeczywistość może być przedmiotem poznania intelektualnego, jednak istnieje inny sposób poznania, jest to intuicja, która może mieć charakter aktu momentalnego, nagłego, który całość obejmuje w sposób syntetyczny. Takie intuicje duchowe mogą dotyczyć, np. rozpoznania powinności moralnych, gdyż prawdy o charakterze duchowym nie ograniczają się tylko do poznania substancji i przyczyn, ale dotyczą też uświadomienia sobie celów. Mistyka jest przez Lutosławskiego rozumiana w sposób szeroki - dotyczy ona zarówno świata materialnego, jak i duchowego, w którym na szczycie hierarchii znajduje się Bóg. W tym miejscu punkt widzenia filozofa w sposób szczególny upodabnia się do tego, który mogliśmy znaleźć w wierszu Widzenie. Jednocześnie powołując się na opinię jezuity o. Poulaina, filozof przestrzega przed utożsamianiem ekstazy mistycznej ze zjawiskami paranormalnymi, zwłaszcza wywoływanymi za pomocą technik mediumicznych ${ }^{15}$. Jego zdaniem inicjacja ezoteryczna prowadzi do mocy, a nie do wiedzy. Dodać należy, że niechęć Lutosławskiego wobec praktyk tajemnych wzrosła około roku 1900 - miało to związek z jego nawróceniem ${ }^{16}$.

Wielość czynników poznania - zmysły, intelekt, wola i natchnienie - znajduje swoje odzwierciedlenie $\mathrm{w}$ stworzonej przez polskiego myśliciela koncepcji kolejnych faz rozwoju doktryn filozoficznych. Rozwój zaczynał się od materializmu, po czym poprzez idealizm dochodził do fazy panteizmu. Następną formą stał się spirytualizm, który utorował drogę mistycyzmowi. W owych systemach może jednak dojść do jednostronności, która charakteryzuje zarówno poznanie własnej jaźni, jak i Boga, dlatego też Lutosławski postuluje uwzględnienie kolej-

13 W. Lutosławski, Filozofia narodowa polska, w: Spór o charakter narodowy filozofii polskiej. Antologia tekstów 1810-1946, pod red. Stanisława Pieroga, WFiS UW, Warszawa 1999, 396-397.

14 W. Lutosławski, L’extase mystique, dz. cyt., s. 151.

15 Tamże, s. 150.

16 A. Świerzowska, Esoteric Influences in Wincenty Lutosławski's Programme of National Improvement. Prolegomena, „The Polish Journal of the Arts and Culture” 2015, No. 13(1), s. 156. 
nego (wydaje się, że doskonalszego) czynnika ludzkiej świadomości, którym jest świadomość narodowa. Zdaniem filozofa jest to forma poznania, która w chwili obecnej dopiero zaczyna się ujawniać17. Naród nie jest zwyczajną i naturalną rzeczywistością, dlatego też jego poznanie ma uprzywilejowaną pozycję: „Naród jest to grupa duchów mających wspólne powołanie, czyli wspólny cel. Powołanie pochodzi od Boga, więc w świadomości narodowej tkwi doznanie Boga mistyczne"18. Jeśli taka jest wizja poznania więzi narodowej, to naród musi być rozumiany jako rodzaj wspólnoty religijnej.

\section{Wincentego Lutosławskiego koncepcja religii narodu: zakon, śluby zakonne, wódz}

Na poglądy Lutosławskiego w kwestii narodowej niewątpliwie miało wpływ to, że duża część jego rodziny należała do Ligi Narodowej. Przez pewien czas on również należał do Ligi, jednak Dmowski i politycy endeccy (nazywani przez filozofa „zgrają”) zniechęcili go do siebie. Z czasem filozof stwierdził, że ideologię endecką przenikał ,jad pozytywizmu”'19.

Lutosławski w Filozofii narodowej stwierdza, że filozofia zazwyczaj szuka prawd ogólnych, stąd też hasło tworzenia doktryn o szczególnym charakterze lokalnym w pierwszej chwili może wydawać się dziwne ${ }^{20}$. Jednak wbrew temu to prawdziwy naród stanowi najważniejszy i najbardziej interesujący przedmiot badań metafizycznych. Dodajmy, że zdaniem neomesjanisty „naród” jest podstawowym pojęciem polskiego poglądu na świat ${ }^{21}$.

Liczba prawdziwych narodów jest ograniczona, gdyż to Opatrzność powołuje do istnienia owe wspólnoty i filozofia wyrasta z ich życia. Zdaniem Lutosławskiego każda taka społeczność wnosi swój wkład do filozofii całej ludzkości ${ }^{22}$. Stąd widać, że można mówić nie o jednej, lecz o wielu filozofiach narodowych, które współtworzą wspólne dziedzictwo całej ludzkości. Jeśli chodzi o zróżnicowanie

\footnotetext{
17 W. Lutosławski, Filozofia narodowa polska, dz. cyt., s. 396-397.

18 Tamże, s. 397.

19 W. Lutosławski, Jeden łatwy żywot, Fundacja im. Wincentego Lutosławskiego, Kraków 1994, s. 249-250; T. Mróz, Wincenty Lutosławski (1863-1954), dz. cyt., s. 169-172.

20 W. Lutosławski, Filozofia narodowa, [odbitka z „Przeglądu Filozoficznego”] Warszawa 1934, s. 1.

21 W. Lutosławski, La philosophie peut-elle être nationale?, [b. m.] 1934, s. 16; Wincenty Lutosławski, Filozofia narodowa, dz. cyt., s. 2.

22 W. Lutosławski, Filozofia narodowa, dz. cyt., s. 2.
} 
ducha poszczególnych doktryn, to Lutosławski ukazuje przykład Polski i Francji: „Podobnie jak dla spirytualizmu francuskiego nieśmiertelność duszy indywidualnej była naczelnym dogmatem, w filozofii narodowej polskiej takim dogmatem jest nieśmiertelność i niezniszczalność prawdziwych narodów"23.

Co stanowi najgłębszą naturę więzi zespalającej narody? Lutosławski powołuje się na przykład codziennych relacji międzyludzkich i porównuje więź narodową do miłości romantycznejej ${ }^{24}$ Wydaje się jednak, że w myśli Lutosławskiego istotniejszą rolę pełni inna analogia: „Grupa duchów zdolnych do wzajemnej najintensywniejszej przyjaźni tworzy naród, a świadomość narodowa jest uczuciem, które takie duchy łączy. Szczeble świadomości narodowej są tak liczne, że nie mieszczą się w jednym doczesnym żywocie" 25 . Zwróćmy uwagę na powiązanie teorii duchowej przyjaźni z koncepcją reinkarnacji (Lutosławski często używa słowa „palingeneza”) - zdaniem neomesjanisty ludzie żyją zbyt krótko, aby więź mogła stać się wystarczająco dojrzała. Niezależnie od tego, jaką byśmy się posłużyli analogią, to świadomość narodowa jest według filozofa uczuciem nowym i tak różni się od patriotyzmu starorzymskiego, jak chrześcijaństwo od poprzedzającego go zabobonnego pogaństwa ${ }^{26}$.

To nowe poczucie więzi tworzy głęboką jedność członków wewnątrz własnej społeczności, ale według Lutosławskiego musi być z nim związany szacunek względem przedstawicieli innych narodów ${ }^{27}$. Rzeczników takiej postawy neomesjanista określa mianem „nacjonalistów” - są to ci, którzy chcą wolności dla swojego i dla innych narodów, aby każda społeczność mogła żyć własnym życiem na własnym terytorium i nie poddana opresji ze strony innych ${ }^{28}$.

Warto może przytoczyć te słowa filozofa, w których on najdobitniej chyba ukazał quasi-religijny, a może nawet nadreligijny charakter więzi narodowej:

Miłość do naszego narodu prowadzi do ogromnego bogactwa siły twórczej, większego niż miłość względem naszych współwyznawców. Chrześcijaństwo, które było rozpowszechnione aż do czasu objawienia się świadomości narodowej, doskonaliło jednostki i ich relacje względem innych jednostek. Świadomość narodowa ma doskonalić narody i ich relacje międzynarodowe, aby je

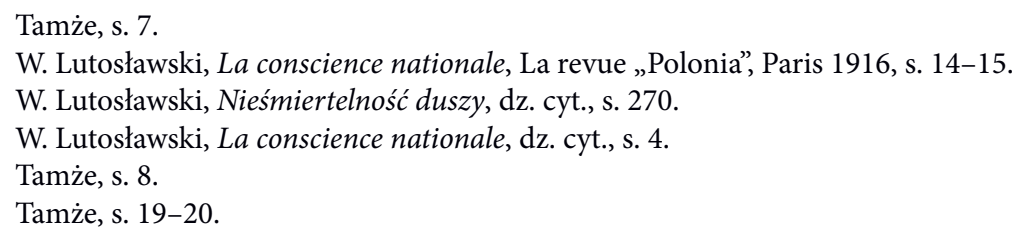


uczynić tak doskonałymi, jak w życiu chrześcijańskim w najczystszej postaci mamy to w postaci relacji między świętymi ${ }^{29}$.

Zdaniem Lutosławskiego historia Polski po rozbiorach udowodniła, że naród może istnieć bez państwa, w związku z czym narodu nie da się utożsamić ani z państwem, ani z plemieniem dominującym na terytorium państwa. Naród również nie jest rodzajem wspólnoty o charakterze biologicznym:

Świadomość narodowa łączy nie ciała tej samej rasy, lecz duchy mające dążenia wspólne. Każde grono ludów, które staje się narodem, wyrzeka się przesądu wyższości jednej rasy nad drugimi. Aby dokonać asymilacji wzajemnej wszystkich pierwiastków, naród łączy jednostki różnego pochodzenia [...], skoro chodzi o unicestwienie tych różnic w jedności duchowej wyższego rzędu ${ }^{30}$.

Unicestwienie różnic między jednostkami i zespolenie ich w jedność - czyż nie pasuje to do opisu ekstazy mistycznej?

Quasi-religijne pojmowanie zjawiska narodu przez Lutosławskiego doprowadziło go do postulatu stworzenia wspólnot, które swoim sposobem funkcjonowania przypominają zakony. Stwarzając obraz nowego typu organizacji, nawiązał do zawodu kowala - kowale mieli być w owej wizji pionierami pogłębionego sposobu widzenia patriotyzmu, kuźnica zaś miała być instytucją, w której „kowalstwo" miało być praktykowane.

Zdaniem filozofa naturę wspólnoty narodowej tworzy podzielany przez wszystkich sposób myślenia, który - jak wcześniej pokazaliśmy - określony jest mianem świadomości narodowej. Ów stan wymaga kształtowania i doskonalenia, do czego potrzebne są specjalne instytucje różniące się od typowych szkół i uniwersytetów. Taką funkcję mają spełniać specjalne placówki zwane przez Lutosławskiego „kuźnicami”31. Nie sposób tutaj nie zauważyć analogii z innymi ruchami i organizacjami o charakterze światopoglądowym, które swoje nazwy czerpały od nazw różnych zawodów, takich jak wolnomularstwo, czy też węglarstwo. Jednak sam pomysłodawca idei kuźnic wprost do owych ruchów się nie odwoływał - raczej widział siebie jako kontynuatora szkół filozoficznych starożytnej Grecji - Akademii, Liceum, czy też szkół stoickich i epikurejskich. Jeśli

\footnotetext{
29 Tamże, s. 32, przekład własny.

30 W. Lutosławski, Filozofia narodowa, dz. cyt., s. 1.

31 W. Lutosławski, Potrzeba Kuźnicy, Księgarnia i Drukarnia Katolicka, Katowice 1933, s. 3.
} 
idzie o instytucje katolickie, to odwoływał się do aktywności zakonów Michaelitów oraz Urszulanek Szarych ${ }^{32}$. Tu trzeba uczynić kolejną uwagę - jeśli idzie o nawiązywanie do tradycji starożytnych szkół filozoficznych, to w przypadku Lutosławskiego można również dostrzec pewne analogie do szkoły pitagorejskiej.

Lutosławski postulował, aby kuźnice pełniły rolę miejsc, w których miałyby się odbywać rekolekcje narodowe (termin użyty przez samego pomysłodawcę owych instytucji!), podczas których Polacy mogliby pogłębiać swoje poczucie tożsamości; z kolei cudzoziemcy w owych centrach mieliby szansę poznać naturę i powołanie narodu. Kuźnice powinny prowadzić działalność edukacyjną, nie tylko organizując różnego rodzaju spotkania i kursy, ale również za pomocą publikacji w języku polskim i w językach obcych ${ }^{33}$.

Zastosowanie pojęć i terminów wziętych $\mathrm{z}$ tradycji katolickiej nie ograniczyło się do mówienia o zakonie i rekolekcjach - Lutosławski postulował, aby kuźnice pełniły rolę „seminarium wychowania narodowego dla misjonarzy myśli polskiej" ${ }^{34}$. Owa funkcja misjonarska miałaby polegać na propagowaniu najbardziej doniosłych dzieł kultury ${ }^{35}$. W dalszej części swojej publikacji filozof opisał kilka takich ośrodków, które na przestrzeni wielu lat udało mu się stworzyć w różnych krajach świata ${ }^{36}$.

Kowale mieszkający razem mieli tworzyć kuźnice, czyli - jak to określił Lutosławski - „klasztory nowoczesne” ${ }^{37}$. Ich podstawowe działania zostały określone w formule „praca, zabawa, modlitwa, twórczość”38. Filozof szczególną rolę przypisywał zachowaniu równowagi między pracą i zabawą (rozrywką) - praca potrzebuje właściwej rozrywki, a zarazem służba na rzecz szlachetnej zabawy (praca w teatrze czy organizacja wycieczki) może być pracą. Jeśli praca wraz $\mathrm{z}$ rozrywką odbywają się w nieustannym trwaniu przy Bogu, stają się rodzajem modlitwy. Życie we wspólnocie z Bogiem sprawia, że praca zostaje podniesiona na poziom twórczości ${ }^{39}$.

Kuźnice będą mogły oddawać się różnym zadaniom, które będą zależały od umiejętności posiadanych przez kierowników, jednak najpilniejsze wydaje się

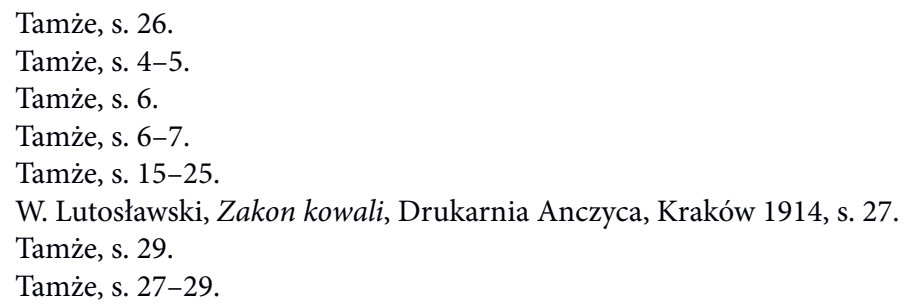


utworzenie ośrodków wydających dobre książki propagujące polskość. Niezależnie jednak od typu zajęcia jest rzeczą konieczną, aby każda $\mathrm{z}$ takich instytucji posiadała własne dochody, aby utrzymywała się z owoców pracy członków ${ }^{40}$.

Jeśli idzie o niektóre aspekty funkcjonowania wewnątrz wspólnot, to Lutosławski zaleca ostrożność w przyjmowaniu ludzi samolubnych, nieufnych i niechętnie nastawionych do innych. Poza tym przestrzega przed tymi, którzy potrafią pięknie mówić i pisać o wyższych ideałach, natomiast w praktyce okazują się być kimś, kto wykorzystuje pracę i ofiarność innych. Filozof domaga się, aby wszyscy członkowie kuźnicy uczestniczyli w pracach fizycznych i aby nie zwalniały $z$ tego ani ani wykształcenie, ani ofiary pieniężne wniesione na rzecz owej instytucji. Zakres obowiązków ma być regulowany jedynie przez potrzeby kuźnicy oraz możliwości członków ${ }^{41}$.

Lutosławski uważał, że w większości wypadków pobyt w kuźnicach powinien być czasowy - po pewnym okresie spędzonym w takim ośrodku kowal powinien albo wrócić do swojej aktywności, albo sam założyć nową kuźnicę ${ }^{42}$.

Przedstawione zadanie tworzenia specjalnych ośrodków edukacyjno-formacyjnych zakłada potrzebę powołania specjalnych zespołów, które będą w stanie je prowadzić. Owe wspólnoty Lutosławski pojmuje jako swojego rodzaju zakony, które maja być związane więzami ślubów. Filozof z góry jednak odrzuca ślub ubóstwa, gdyż zdaniem filozofa przeczy on zasadzie, że każdy ma dbać o siebie, aby nie być ciężarem dla innych. Odrzuca również ślub czystości, gdyż interes narodu uciskanego (Polska w chwili opublikowania Zakonu kowali była jeszcze pod zaborami) wymaga tworzenia rodzin i wydawania na świat licznego potomstwa. Z kolei ślub posłuszeństwa zakładałby konieczność stworzenia organizacji, która nie byłaby możliwa do utworzenia pod rządami państw zaborczych ${ }^{43}$. Dlatego też zamiast ślubów obecnych $\mathrm{w}$ tradycyjnych zakonach Lutosławski proponuje trzy inne: ślub wierności Bogu, narodowi i wybranemu wodzowi ${ }^{44}$. Trzeba dodać, że Lutosławski dopuszczał sytuację, w której owe śluby mogłyby zostać złożone dożywotnio ${ }^{45}$.

\footnotetext{
40 Tamże, s. 29-31.

41 Tamże, s. 34-35.

42 Tamże, s. 35-36.

43 Tamże, s. 1-3.

44 Tamże, s. 6-s10.

45 Tamże, s. 17.
} 
Filozof wskazuje liczne korzyści, które mają płynąć ze ślubu wierności Bogu: daje on „niezachwianą pogodę ducha, jasność celów i środków swego działania, odwagę wobec niebezpieczeństw i trudności, zrozumienie doniosłości cierpienia i wdzięczność za bóle przez Boga zsyłane"46.

Drugim ślubem jest ślub wierności narodowi, który nakłada na każdego Polaka szczególne obowiązki. Wśród nich pierwszym jest zakaz sprzedawania ziemi obcym oraz staranna jej uprawa. Poza tym należy gospodarkę tak przeorientować, aby nie kierowała się tylko „chciwością zysku i bezdusznym współzawodnictwem", ale żeby była ożywiana duchem narodowym ${ }^{47}$. Następnym obowiązkiem jest ograniczenie się - o ile to możliwe - do kupowania rzeczy wytworzonych przez Polaków. Kupowanie wytworów obcej produkcji jest dopuszczalne tylko wtedy, gdy są one potrzebne, ale są produkowane jedynie przez obcych. Nie jest jednak dopuszczalne kupowanie towarów pochodzących $\mathrm{z}$ państw zaborczych lub wytwarzanych przez członków narodów zaborczych mieszkających na ziemiach polskich. „Czego Polak nie wyrabia, to kupujmy od Francuza, Holendra, Anglika, Szwajcara lub Włocha, pomijając, o ile tylko można, Niemca, Moskala lub Żyda"48. Zastanawiające jest to, że do grupy narodów zaborczych (wrogich?) zostali dołączeni Żydzi, natomiast nie pojawili się tam Austriacy, choć możliwe, że zostali zaliczeni do Niemców.

Wierność narodowi ma się również przejawiać w obszarze kultury - należy inspirować się głównie polskimi wzorcami myśli i sztuki (zwłaszcza literatury) oraz rodzimymi tradycjami i zwyczajami. Lutosławski zwrócił uwagę również na to, że działające na polskich ziemiach partie polityczne (wprawdzie w warunkach zaborczych) kierują się ideami zaczerpniętymi z obcych źródeł - politykę narodową należy zwrócić w stronę ideałów zawartych w polskim dziedzictwie ${ }^{49}$.

Przejdźmy teraz do trzeciego ślubu - ślubu wierności wybranemu przez siebie wodzowi. Zdaniem Lutosławskiego poprzednie śluby bez omawianego obecnie sprawiłyby, że ludzie wierni Bogu i narodowi byliby jedynie zbiorem indywidualistów - dopiero przyjęcie wodza sprawi, że będziemy mieli do czynienia z połączeniem wysiłków. Każdy związany trzecim ślubem ma obowiązek szukania kogoś bliższego Bogu, mądrzejszego i lepszego od siebie, co niewątpliwie będzie miało korzystne skutki dla życia narodowego. Przede wszystkim zapobiegłoby

\footnotetext{
46 Tamże, s. 8.

47 Tamże.

48 Tamże, s. 9.

49 Tamże, s. 9-10.
} 
to wynoszeniu na najwyższe stanowiska w państwie „sprytnych lub pierwotnych warchołów”, a na szczyty wyniesiono by „ludzi duchem najwyższych"50.

Do czego ma zobowiązywać ślub posłuszeństwa wodzowi? Otóż trzeba mu stale relacjonować nasze postępowanie oraz nie czynić niczego ważnego bez jego zgody, należy także wykonywać również jego polecenia - z wyjątkiem tych, które sprzeciwiałyby się naszemu sumieniu. Do spraw, które należałoby konsultować z wodzem, Lutosławski zalicza np. zawieranie małżeństwa oraz rozporządzanie majątkiem. Kowale powinni nadto przekazywać wodzowi część swojego majątku oraz dochodów, co sprawi, że wodzowie mający więcej zwolenników będą mieli większe środki do dyspozycji. W zamyśle pomysłodawcy zakonu kowali ma to spowodować, że największe środki będą posiadali ci, którzy będą najwyżsi duchem, i to pozwoli im realizować ich ideały ${ }^{51}$.

Filozof przypomina, że ślub ma dotyczyć posłuszeństwa dowolnie wybranemu wodzowi, w związku z czym pozwala to na zmianę przełożonego, ale uznanie nowego musi nastąpić natychmiast po odrzuceniu starego. Jednak nowy wódz powinien porozumieć się ze starym, aby móc poznać kandydata. Lutosławski nie zobowiązuje kowali do tego, aby byli posłuszni przez całe życie jednemu wodzowi, ale $\mathrm{z}$ drugiej strony postuluje wprowadzenie procedur utrudniających zmianę i gwarantujących większą stabilizację ${ }^{52}$. W kwestii wyboru wodza pomysłodawca zakonu kowali głosi jednak zasadę, że nikt nie powinien samego siebie proponować innym jako życiowego przewodnika, co najwyżej może przyjąć od innych propozycję poddania się jego kierownictwu $\mathrm{u}^{53}$.

Pomysłodawca zakonu kowali dopuszcza jednak i taką sytuację, w której ktoś będzie miał nad sobą Wodza jedynego w swoim rodzaju - Boga - i tylko jemu będzie bezpośrednio posłuszny. Tacy kowale są ludźmi, którzy nauczyli się rozumieć wolę Bożą. Jak dodaje filozof, „takich ludzi nazywamy czynicielami Sprawy i odróżniamy ich od uczestników Sprawy"54. Jednak nie wystarczy, aby ktoś sam uznał siebie za czyniciela - trzeba, aby ktoś był za takiego uznany przez innych, czyli aby znalazł tych, którzy mu się powierzą ${ }^{55}$.

\footnotetext{
Tamże, s. 10-11.

Tamże, s. 11-13.

Tamże, s. 12.

Tamże, s. 15.

Tamże, s. 25.

Tamże.
} 
Zdaniem Lutosławskiego trzy proponowane przez niego śluby mogą zaowocować wspaniałymi przymiotami charakteru, które w tradycyjnej terminologii można by nazwać cnotami. Do takich dodatnich cech należy zaliczyć w pierwszym rzędzie dzielność, rzetelność i przyjaźńn ${ }^{56}$. Poza tym Lutosławski wielką wagę przywiązuje do szeroko pojętej wstrzemięźliwości, w tym również do wolności od nałogów - od obżarstwa, rozpusty i hazardu. Interesujące jest to, że do nałogów zaliczono również lenistwo, gadatliwość i skłonność do kłamstwa ${ }^{57}$.

Do interesujących aspektów myśli Lutosławskiego należy zaliczyć jego poglądy dotyczące relacji między mężczyznami i kobietami, szczególnie relacjami realizującymi się $\mathrm{w}$ małżeństwie. Owa wspólnota życia została przez filozofa określona jako jedna z form bezpośredniego obcowania z Bogiem. Doskonałe małżeństwo polega na tym, że mąż i żona są wodzami dla siebie nawzajem - ma to polegać na tym, że każdą ważną decyzję podejmują wspólnie. Pomysłodawca zakonu kowali akcentuje, z jednej strony, równość mężczyzny i kobiety, choć dostrzega twórczy element różnicy i wzajemnego uzupełniania się $e^{58}$.

Może krótko tylko wspomnijmy o pewnym aspekcie relacji, które łączyły neomesjanistę z jego uczniami: oficjalnie używali w stosunku do niego tytułu „Ojciec", ale nieoficjalnie mówili o nim „Lutos”59.

\section{Podsumowanie}

Podsumowując analizy myśli Lutosławskiego, trzeba powtórzyć tezę zawartą w początkowym fragmencie artykułu: filozof nakreślił wizję narodu pojętego jako wspólnota religijna, co musi budzić zastrzeżenia zarówno z chrześcijańskiego, jak i świeckiego punktu widzenia. Naród został - według Lutosławskiego - ustanowiony przez samego Boga, łączące go wewnętrzne więzi przypominają zjednoczenie o charakterze mistycznym i mogą być doskonalone w powtarzających się wciąż inkarnacjach jego członków. Obecność wyżej wymienionych poglądów została potwierdzona w świetle analizy pism filozofa.

\footnotetext{
56 Tamże, s. 17-20.

57 Tamże, s. 21-25.

58 Tamże, s. 26.

59 T. Mróz, Wincenty Lutosławski (1863-1954). Jestem obywatelem utopii, PAU, Kraków 2008, s. 133.
} 
Dodatkowo niepokój musi budzić idea posłuszeństwa wodzowi, gdyż zawiera ona $\mathrm{w}$ sobie zarodki totalitaryzmu. Wodzowie wraz z podległymi im adeptami mogliby tworzyć sieć nieformalnych grup nacisku zakłócających właściwe funkcjonowanie polityki i ekonomii odrodzonego państwa polskiego. Niesmak musi również budzić zaliczenie Żydów do wrogów Polski (zostali oni wymienieni w jednym rzędzie z Niemcami i Moskalami!) i de facto postulowanie objęcia ich bojkotem ekonomicznym.

$\mathrm{Z}$ drugiej strony trzeba stwierdzić, że zaangażowanie Lutosławskiego w krzewienie postaw patriotycznych w okresie zaborów zasługuje na najwyższe uznanie. Wśród ludzi uformowanych przez filozofa można znaleźć wiele wybitnych jednostek. Do założonego przez filozofa abstynenckiego stowarzyszenia „Eleusis" należeli np. Stanisław Pigoń, czy też Olga i Andrzej Małkowscy. Dzięki tym ostatnim w Prawie Harcerskim znalazł się nakaz abstynencji od tytoniu i alkoholu ${ }^{60}$.

Podczas lektury niniejszego artykułu mogło paść pytanie o związek myśli Lutosławskiego z filozofią indyjską. Które to elementy myśli i praktyki Lutosławskiego mogą prowokować do postawienia takiej kwestii? Wydaje się, że przede wszystkim propagowanie abstynencji (żeby nie powiedzieć: ascezy), wiara w reinkarnację oraz opisane wcześniej przekonanie, że każdy człowiek jest odwiecznie istniejącym duchem.

Trzeba stwierdzić, że zasadnicze zręby owego światopoglądu powstały, zanim w 1903 roku filozof poznał Mieczysława Geniusza, a to właśnie on miał jako pierwszy zapoznać Lutosławskiego z myślą Wschodu ${ }^{61}$.

Przekonanie o własnym odwiecznym istnieniu duchowym brało się z opisanego wcześniej nadzwyczajnego doświadczenia wewnętrznego, które - przypomnijmy - miało miejsce w 1885 roku. Mniej więcej w tym samym czasie Lutosławski stał się zwolennikiem doktryny reinkarnacji ${ }^{62}$. Spirytualizm oraz postulat daleko idącego umiaru w dziedzinie seksualnej filozof wywodził z greckich dok-

60 E. Głowacka-Sobiech, Wychowanie ku „najwyższym” wartościom w działalności i programie „Eleusis” w okresie niewoli narodowej, „Biuletyn Historii Wychowania” 2005/2006, nr 1-2, s. 5657.

${ }_{61}$ T. Podgórska, Stowarzyszenie patriotyczno-religijne „Eleusis” w latach 1902-1914, Katolicki Uniwersytet Lubelski, Wydział Nauk Społecznych, Lublin 1999, s. 24-25.

62 Tamże, s. 17. 
tryn misteryjnych, dlatego też założonemu przez siebie bractwu abstynenckiemu nadał nazwę „Eleusis"63.

Nawiązanie do kultu Demeter i Persefony było dopuszczalne, choć nieprecyzyjne, gdyż spirytualizm, doktryna reinkarnacji i ideały umiarkowania były związane przede wszystkim z orfizmem i pitagoreizmem. Jednak zdaniem Waltera Burkerta starożytne formacje kultowe i światopoglądowe wzajemnie przenikały się - np. jeden i ten sam człowiek mógł jednocześnie uczestniczyć w misteriach eleuzyńskich i być zwolennikiem pitagoreizmu lub orfizmu ${ }^{64}$.

Niezależnie od zgłaszanych wyżej uwag jest kwestią bezsporną to, że po 1903 roku (a więc już po założeniu „Eleusis”) Wincenty Lutosławski zetknął się z systemami religijno-filozoficznymi Wschodu, przy czym na szczególną uwagę zasługuje jego fascynacja jogą. Z czasem stał się jej wielkim propagatorem, a niektóre związane $\mathrm{z}$ nią praktyki na pewien czas zdołał narzucić członkom założonego przez siebie bractwa abstynenckiego ${ }^{65}$.

Na sam koniec trzeba dodać, że plany Lutosławskiego zostały skorygowane przez wypadki historyczne. Idea kuźnic oraz zakonu kowali powstała na początku XX wieku, jeszcze przed wybuchem wojny. Znaczące w tym kontekście są słowa kończące Zakon kowali:

A objawienie tej Polski, która będzie, dane nam w jasnowidzeniach naszych wieszczów i myślicieli, wymaga naszego czynu własnego, by stało się ciałem. Czyn ten od nas zależy, nie ma przemocy, która mogłaby temu zapobiec. Prawdą wiekuistą pozostają słowa Konrada uwięzionego: „Ludzie, każdy z was mógłby, samotny, więziony - myślą i wiarą zwalać i podźwigać trony”66.

Dodajmy, że na końcu tekstu Lutosławski umieścił datę napisania książki: 24 czerwca 1914 r. Miesiąc później wybuchła pierwsza wojna światowa, która diametralnie zmieniła sytuację Polski.

63 Tamże, s. 9, 30-31; E. Głowacka-Sobiech, Wychowanie..., dz. cyt., s. 52.

${ }^{64}$ W. Burkert, Orfizm i misteria bakchiczne. Nowe świadectwa $i$ stare problemy $z$ interpretacja, przeł. Karolina Sekita, „Kronos: Metafizyka, Kultura, Religia” 2011, nr 4, s. 111-113.

65 E. Głowacka-Sobiech, Wychowanie..., dz. cyt., s. 53.

66 W. Lutosławski, Zakon kowali, dz. cyt., s. 40. 


\section{Bibliografia}

Burkert W., Orfizm i misteria bakchiczne. Nowe świadectwa i stare problemy z interpretacja, przeł. Karolina Sekita, „Kronos: Metafizyka, Kultura, Religia” 2011, nr 4.

Floryńska H., Problematyka filozoficzna neoromantyzmu i Młodej Polski, w: Zarys dziejów filozofii polskiej 1815-1918, pod red. Andrzeja Walickiego, PWN, Warszawa 1983.

Głowacka-Sobiech E., Wychowanie ku „najwyższym” wartościom $w$ działalności i programie „Eleusis” w okresie niewoli narodowej, „Biuletyn Historii Wychowania" 2005/2006, nr 1-2.

Kłoczowski J.A., Profesor Henryk Elzenberg o religii i mistyce, „Znak - Idee” 1990, t. 3.

Lutosławski W., Filozofia narodowa, [odbitka z „Przeglądu Filozoficznego”] Warszawa 1934 [streszczone tłumaczenie wykładu wygłoszonego na kongresie w Pradze 7 IX 1934].

Lutosławski W., Filozofia narodowa polska, w: Spór o charakter narodowy filozofii polskiej. Antologia tekstów 1810-1946, pod red. Stanisława Pieroga, WFiS UW, Warszawa 1999.

Lutosławski W., Jeden łatwy żywot, Fundacja im. Wincentego Lutosławskiego, Kraków 1994.

Lutosławski W., La conscience nationale, La revue „Polonia”, Paris 1916.

Lutosławski W., La philosophie peut-elle être nationale?, [b. m.] 1934.

Lutosławski W., L'extase mystique, Hermann, Paris 1937 [Travaux du IX Congrès International de Philosophie - Extrait].

Lutosławski W., Nieśmiertelność duszy. Zarys metafizyki polskiej, Arct, Warszawa 1925.

Lutosławski W., Potrzeba Kuźnicy, Księgarnia i Drukarnia Katolicka, Katowice 1933.

Lutosławski W., Zakon kowali, Drukarnia Anczyca, Kraków 1914.

Adam Mickiewicz, Widzenie, w: tegoż, Dzieła, t. I, „Czytelnik”, Warszawa 1955.

Mróz T., „Metafizyka” Wincentego Lutosławskiego, w: W. Lutosławski. Metafizy$k a$, Muzeum Przyrody w Drozdowie, Drozdowo 2004.

Mróz T., Wincenty Lutosławski (1863-1954). Jestem obywatelem utopii, PAU, Kraków 2008. 
Podgórska T., Stowarzyszenie patriotyczno-religijne „Eleusis” w latach 1902-1914, Katolicki Uniwersytet Lubelski, Wydział Nauk Społecznych, Lublin 1999. Świerzowska A., Esoteric Influences in Wincenty Lutosławski's Programme of National Improvement. Prolegomena, „The Polish Journal of the Arts and Culture" 2015, No. 13(1).

\section{Streszczenie}

Wincenty Lutosławski stworzył koncepcję quasi-religijną narodu, którego członkowie są połączeni więzią o charakterze przypominającym zjednoczenie mistyczne. Prawdziwe narody są zdaniem filozofa tworzone przez Boga i ich liczba jest ograniczona. Dodać należy, że koncepcja Lutosławskiego była tworzona w sytuacji, gdy Polska była na ponad 100 lat wymazana $\mathrm{z}$ mapy świata. W celu umocnienia kondycji narodu Lutosławski postulował utworzenie Zakonu Kowali, którego celem miała być edukacja patriotyczna. Koncepcje głoszone przez filozofa (np. doktryna reinkarnacji) były odległe od zasad katolickiej ortodoksji.

Słowa kluczowe: naród, religia, mistyka, zakon

\section{Summary}

\section{Wincenty Lutosławski's Religion of the Nation}

Wincenty Lutosławski created a quasi-religious concept of a nation whose members are connected by a bond reminiscent of mystical union. True nations, according to the philosopher, are created by God and their number is limited. It should be added that Lutosławski's concept was created when Poland was erased from the world map for over 100 years. In order to strengthen the condition of the nation, Lutosławski called for the creation of the Blacksmith Order, whose aim was to be patriotic education. The concepts advocated by the philosopher (e.g., the doctrine of reincarnation) were far from the principles of Catholic orthodoxy.

Key words: nation, religion, mysticism, religious order 